\title{
GYÓGYNÖVÉNYEK SZEREPE A TURIZMUSBAN ÉS AZ EGÉSZSÉGÜGYBEN
}

\author{
Pászk Norbert \\ mestertanár, Miskolci Egyetem, Elméleti Egészségtudományok Intézete \\ 3515 Miskolc, Miskolc-Egyetemváros, e-mail: efkpaszk@uni-miskolc.hu
}

\begin{abstract}
Absztrakt
A projekt időszakában fitoterápiával, azaz gyógynövénygyógyászattal kapcsolatban végeztem föként kutatásaimat, irtam meg publikációimat és népszerüsitettem a gyógynövényeket különbözö rendezvényeken, programokon, föleg az egyetem hallgatói számára. A gyógynövények használata reneszánszát éli, az emberek ismét visszatérnek a természethez, újra felfedezik a gyógynövényeket és azok jótékony hatását, valamint egyre nagyobb mértékben kezdenek feléjük fordulni a gyógyulni vágyók, valamint az egészséges életmódot fontosnak tartó emberek. Magyarország gyógynövény nagyhatalomnak számit, 400 körüli gyógynövény fajtájával, azonban az adottságokat, lehetöségeket nem használjuk ki eléggé, pedig a gyógynövények nélkülözhetetlenek az emberek számára és a hazai turizmuson, egészségturizmuson belül is jelentős szerepet játszhatna a gyógynövényturizmus, mint ágazat.
\end{abstract}

Kulcsszavak: gyógynövények, egészségturizmus, egészség

\begin{abstract}
During the project period, I mainly did my research from medical herbs, wrote my publications and promoted herbs at various events and programs, mainly for the university students. The use of medical herbs is in a renaissance era, people are returning to nature, rediscovering herbs and their beneficial effects, and more and more people wanting to heal and people who want a healthy lifestyle are turning to them. Hungary is a great power of herbs, with about 400 types of herbs, however, the potentials and opportunities are not sufficiently exploited, though herbs are essential for people and herbal tourism as a sector could play a significant role in tourism and health tourism.
\end{abstract}

Keywords: medical herbs, healthturism, health

\section{Bevezetés}

A fitoterápia, azaz a gyógynövénygyógyászat egy komplex ősrégi gyógyászati rendszer, mely betegségek megelőzésére és gyógyítására egyaránt alkalmas. Magába foglalja a gyógynövények, füszernövények, gyógyító tápláléknövények (gabonafélék, zöldségek, gyümölcsök), apiterápiás (méhészeti termékek) és aromaterápiás (illóolajok) termékek használatát, valamint a gyógyító gombák ismeretét is.

A tudományág elnevezése Henri Leclerc (1870-1955) francia orvosnak köszönhető, aki előnyben részesítette orvosi pályafutása során a természetes anyagokat, ezen belül pedig leginkább a gyógynövényeket.

A Földön nagyjából 50 ezer olyan növény található, ami jelenlegi tudásunk szerint gyógyhatással rendelkezik, ez csaknem $10 \%$-a az összes eddig felfedezett növénynek, ami igazán jelentős szám. 
Hazánk területén pedig körülbelül 400 gyógyító növény található, ami nagyon soknak számít európai szinten is a többi országban találhatóhoz képest. Ez többek között a rendkívül optimális klimatikus viszonyoknak is köszönhetö.

A fitoterápiában jelenleg a népgyógyászat és a modern gyógynövényhasználat elemei egyaránt megtalálhatóak. Régebben, a 20. század előtt, még inkább a népi gyógyászat volt használatos, mivel akkoriban még nem ismerték megfelelően a gyógynövények hatóanyagait és nem tudták, hogy milyen esetleges veszélyeket (mellékhatások, ellenjavallatok, kölcsönhatások) rejthet a használatuk és hogy nem minden növény alkalmazható folyamatosan, nagy mennyiségben. Manapság már inkább a modern, hatóanyagok ismeretén alapuló gyógynövényhasználat népszerü a szakemberek körében, amely hatékonyabb és biztonságosabb körülményeket biztosít a felhasználás során. Ahogy elkezdték felfedezni a gyógynövények hatóanyagait egyre nagyobb tudásra tettek szert a kutatók és a fitoterapeuták, azonban még mindig rengeteg felfedezésre, további kutatásra váró növény létezik a Földön, amelyek akár ma még gyógyíthatatlannak tűnő betegségek kezelésére is alkalmasak lehetnek majd a közeljövőben. Azonban a gyógynövények nem helyettesítik az orvosi kezelést, csak komplementer medicinaként használhatók [13, 14].

Magyarország egészen az 1980-as évekig gyógynövény termesztő nagyhatalomnak számított. Nem csak a termesztés körülményei nagyon kedvezőek hazánkban, hanem a vadon termő növények sokasága is jellemzi térségünket. Magyarországon több, mint 400 féle gyógynövény terem, így sokhoz csak saját gyüjtés útján lehet hozzájutni. A múlt században hazánk évtizedeken keresztül az egész európai piac körülbelül hatvan százalékát látta el gyógynövénnyel. A kedvező természeti viszonyoknak köszönhetően világviszonylatban még mindig vezető helyen vagyunk a termesztett fajták számával. A termesztett és gyüjtött gyógynövényeknek nagyjából hetven százalékát exportáljuk [10].

Ma azonban a gyógynövény termesztésre használt termőterület alig 20 ezer hektárt tesz ki, így a gyógynövények termesztése a korábbi termőterületnek csupán a töredékén folyik. Kereslet most is lenne a magyar gyógynövényekre, ugyanis az ágazat még mindig feltörekvőben van a világon, ahogy egyre többen fordulnak a gyógynövények felé. Ennek ellenére kevesen kezdenek újonnan gyógynövénytermesztésbe, a meglévő gazdálkodók többsége pedig az időjárás viszontagságai, vagy éppen a szegmens egyre rosszabb támogatottsága miatt inkább abbahagyta a termesztést és mással próbálkozik [10,21].

Termőföldjeinken lehetőségünk lenne gyógynövény termesztés elindítására, a megtermesztett alapanyagokból különböző gyógyhatású készítmények (olajok, tinktúrák, kenőcsök szörpök, lekvárok, teák) előállítására és azok árusítására, a helyi és külföldi termelői piacokon megjelenni termékeinkkel [10].

Vidéken, a falvakban a mai napig nagy hagyománya van a gyógyító növények ismeretének, viszont a lakosság elöregedésével egyre csökken a megfelelő tudással rendelkező füvesemberek, javasasszonyok száma. Pedig ezt a tudást mindenképp meg kellene örökíteni az utókor számára [13].

Egyes becslések szerint közel 50 ezer embert foglalkoztat a gyógynövényágazat jelenleg hazánkban, ami még mindig elég jelentősnek mondható. Nagy szerepet kap az ágazat a vidéki munkahelyteremtésben, a hátránya viszont az, hogy leggyakrabban csupán szezonális munkalehetőséget biztosít az embereknek a gyüjtések vagy éppen az ismertető programok, túrák során [21].

Rengeteg érdeklődő van a gyógynövények iránt, bármilyen hozzájuk kapcsolódó programról is legyen szó. Nemcsak a felnőtt lakosság, hanem a diákok, fiatalok, gyerekek is igazán nyitottak és fogékonyak rájuk, ahogyan azt tapasztalni lehet. Az előadások, bemutatók során megismerkedhetnek az érdeklődők a legismertebb vagy éppen a már elfeledett gyógynövényekkel. Megtanulhatják melyik 
növény mikor gyüithető, mire használható és hogyan kell felhasználni. A túrák során pedig élőben is megismerkedhetnek a növényekkel a résztvevők.

A probléma az, hogy nagyon kevés a megfelelő minőségü programok száma hazánkban és mennyiségileg szintén rosszul állunk, ugyanis általában csak szezonálisan és évente párszor találkozhatunk ilyen programokkal a különbözö térségekben. Tehát nagy szükség lenne ezekre a programokra, annak érdekében, hogy az információk, tudnivalók megfelelően átadásra kerüljenek az utókor számára és megtanulják az érdeklődők, hogy a házi patikában, a mezőgazdaságban, a kertekben, a konyhában és számos más területen hogyan lehet helyes és biztonságos alkalmazásuk [14, 18, 19, 21].

Magyarország gyógynövényturizmusa egyelőre nem megfelelően kiépített és kihasznált, valamint nagyon változó. Az irodalma pedig még nagyon szegényes, kevés a kutatás és a szakirodalom a témában, igencsak fejlesztésre vár ez a terület.

A gyógynövények megtalálhatók az egészségturizmus, azon belül pedig a wellness és a gyógyturizmus szegmensben is, de nálunk kevésbé jellemzően, mint külföldön. Hazánkban az egészségturizmuson belül lassan önálló helyett kap a gyógynövényturizmus térségünkben is. A gyógynövényturizmust a szabadidős turizmuson belül is el lehet helyezni, de szinte minden turisztikai ágazathoz, területhez kapcsolható [12, 18, 19, 21].

\section{Megbeszélés, következtetés}

A társadalmi tőke egy befektetésre érdemes érték, amire megéri beruházni és figyelmet fordítani. Az egészséges emberek tudnak dolgozni, eredményeket létrehozni, teljes életet élni és legtöbbet tenni a társadalomért. Az egészséges életmódra nevelést, a népegészségügyi programokat már fiatal korban el kellene kezdeni, beleszőve az átadott tudásanyagba a komplementer medicina lehetőségeit, többek között a gyógynövények ismeretét is. A gyógynövények lehetőséget adnak arra, hogy az emberek segítsenek önmagukon, és megtanulják a saját kompetenciahatáraikat az öngyógyítás területén.

Az egészségturizmuson belül sokkal nagyobb hangsúlyt kellene fektetni a gyógynövényekre, mint természetes gyógytényezőkre, ugyanis hatalmas potenciál lenne bennük. Nagyon sok ismeretterjesztő programra, előadásra lenne szükség azonban ahhoz, hogy a tévhiteket eloszlassuk és biztonságosabbá tegyük a házi patikákban is a gyógynövények használatát. Sokan nincsenek tisztában a gyógynövények lehetséges veszélyeivel és meggondolatlanul alkalmazzák öket, aminek nem kívánt, akár súlyos következményei is lehetnek.

A feltárt eredmények tükrében célirányosan lenne érdemes programokat szervezni a még hatékonyabb és biztonságosabb gyógynövényhasználat eléréséhez, valamint a sokkal színesebb és érdekesebb programkínálat érdekében, hogy még sokoldalúbb lehessen a gyógynövényturizmus megjelenése hazánkban is.

\section{Köszönetnyilvánítás}

A cikkben ismertetett kutató munka az EFOP-3.6.1-16-2016-00011 jelü „Fiatalodó és Megújuló Egyetem - Innovatív Tudásváros - a Miskolci Egyetem intelligens szakosodást szolgáló intézményi fejlesztése" projekt részeként - a Széchenyi 2020 keretében - az Európai Unió támogatásával, az Európai Szociális Alap társfinanszírozásával valósult meg.

\section{Irodalom}

[1] Banai, V.: Gyógynövény és drogismeret, Műszaki Könyvkiadó, 2. kiadás, 2005.

[2] Mantovani, L.: Gyógynövények, Tóth Könyvkereskedés és Kiadó Kft. 2009. 
[3] Babulka, P.: Ismerjük fel a vadon termö gyógynövényeket, GABO Könyvkiadó, 2001.

[4] Szendrei, K., Csupor, D.: Gyógynövénytár, Medicina Könyvkiadó Zrt., 2009.

[5] Singh, S., Ernst, E.: Trükk vagy terápia, Park Könyvkiadó, 2008.

[6] Bremness, L.: Füveskönyv, Park Kiadó, 1990.

[7] Melius, P.: Herbárium, Kriterion Könyvkiadó, 1979.

[8] Bingen, von H.: A természet patikája, Budapest-Print Kft., 1998.

[9] Paracelsus: Paragranum, Asztrálfény Kiadó, 1994.

[10] Bernáth, J., Németh, É.: Gyógy-és füszernövények gyüjtése, termesztése, felhasználása, Mezőgazda Kiadó, 3. kiadás, 2007.

[11] Tamasi, J.: Természetgyógyászati alapismeretek, Egészségügyi Nyilvántartási és Képzési Központ, 2017.

[12] Lakatos, M.: Gyógynövényturizmus megjelenése a magyarországi turisztikai termékek piacán, In: Zöld gazdaság és versenyképesség?: XIII. Nemzetközi Tudományos Napok: Gyöngyös, 2012. március 29-30. https://docplayer.hu/106011532-Gyogynovenyturizmus-megjelenese-amagyarorszagi-turisztikai-termekek-piacan-the-presence-of-herbal-tourism-in-among-touristproducts-in-hungary.html (letöltés: 2019.05.20.)

[13] Pászk, N.: Gyógynövények használata a középkorban és ma, Globe Edit kiadó, 2019.

[14] Pászk, N.: A gyógynövények egészségügyi és kulturális szerepe különös tekintettel ÉszakMagyarországra, Miskolci Egyetem, Egészségügyi Kar, 2019

[15] Pászk, N., Kiss-Tóth, E., Kopkáné Plachy, J.: Időskori panaszok és a gyógynövények kapcsolata, Recreation magazin, 2019. tavasz. (2019) pp. 34-37.

https://doi.org/10.21486/recreation.2019.9.1.5

[16] Bernáth, J.: Vadon termö és termesztett gyógynövények, Mezőgazda Kiadó, 2013.

[17] Nemzeti Agrárgazdasági Kamara: Csökken a begyüjtött és termesztett gyógynövények mennyisége, de megforditható a tendencia, In: Nemzeti Agrárgazdasági Kamara honlap, https://www.nak.hu/agazati-hirek/mezogazdasag/146-novenytermesztes/95621-csokken-abegyujtott-es-termesztett-gyogynovenyek-mennyisege-de-megfordithato-a-tendencia (letöltés: 2019.05.21.)

[18] Békés megyei gyógynövény stratégia, In: Békés Megye Önkormányzata honlap, 2016. http://www.bekesmegye.hu/wp-

content/uploads/dokumentumtar/onkormanyzatihivatal/tfo/Gy\%C3\%B3gyn\%C3\%B6v\%C3\%A 9ny.pdf (letöltés: 2019.05.21.)

[19] Gyógynövény-támogatási politikák Szlovákia és Magyarország határ menti régióiban, In: Herbaland.net honlap, 2018.

https://www.herbaland.net/Gy\%C3\%B3gyn\%C3\%B6v\%C3\%A9ny_t\%C3\%A1mogat\%C3\%A 1si_politik\%C3\%A1k_SKHU_r\%C3\%A9gi\%C3\%B3ban.pdf (letöltés: 2019.05.21.)

[20] Erdész F., Kozak, A.: A gyógynövényágazat helyzete, In: Agrárgazdasági Tanulmányok, 2008. 4. szám https://uni-eszterhazy.hu/public/uploads/gyogynovenyagazat-helyzete_5812354905176.pdf (letöltés: 2020.05.21.)

[21] Magyar gyógynövény ágazati stratégia, 2014.

https://uni-eszterhazy.hu/public/uploads/gyogynoveny-strategia-2014_58123569d94f7.pdf (letöltés: 2019.05.21.) 